\title{
MANFAAT MINDFULNESS TRAINING UNTUK MENGURANGI KECEMASAN PADA PASIEN KANKER DENGAN KEMOTERAPI
}

\author{
Jenita DT. Donsu ${ }^{1 *}$, Surantono $^{2}$, Kirnantoro $^{3}$ \\ 1,2,3 Jurusan Keperawatan Politeknik Kesehatan Kemenkes, Jln. Tata Bumi No.3 \\ Banyuraden Gamping Sleman Yogyakarta \\ *E-mail: donsu.tine@gmail.com
}

\begin{abstract}
Anxiety can impair the ability of cancer patients to run chemotherapy. Mindfulness training with meditation methods can improve empathy for self in activating affective, cognitive, moral, intra and interpersonal dimension so as to decrease anxiety especially in cancer patient who will undergo chemotherapy. The purpose of this study was to determine the benefits of mindfulness training in reducing anxiety in cancer patients with chemotherapy. The research method used Quasi experiment design with pretest and posttest control group design, in 60 samples taken at Indonesia Cancer Foundation in Yogyakarta, analyzed with Mann Whitney z distribution test for category ordinal and t-test data for experiment and control group differences. The results showed most of the characteristics of age $>40$ years and female gender with breast cancer type. Conclusions were obtained, mindfulness training can provide benefits for cancer patients in achieving relaxation in order to reduce anxiety when faced with treatment with chemotherapy action, thereby raising awareness to better accept the situation conditions that are happening. Suggestions that health care workers both nurses and doctors can train patients who experience anxiety in the face of chemotherapy or other invasive measures.
\end{abstract}

Keywords: Mindfulness, anxiety, cancer patients

\begin{abstract}
ABSTRAK
Kecemasan dapat mengganggu kemampuan pasien kanker untuk menjalankan kemoterapi. Pelatihan mindfulness dengan metode meditasi dapat meningkatkan empati terhadap diri sendiri dalam mengaktifkan dimensi afektif, kognitif, moral, secara intra dan interpersonal sehingga dapat menurunkan kecemasan terutama pada pasien kanker yang akan menjalani kemoterapi. Tujuan penelitian adalah untuk mengetahui manfaat pelatihan mindfulness dalam menurunkan kecemasan pada pasien kanker dengan kemoterapi. Metode penelitian menggunakan rancangan Quasi eksperiment dengan pretest and posttest control group design, pada 60 sampel yang diambil pada Yayasan Kanker Indonesia di Yogyakarta, dianalisis dengan Mann Whitney test distribusi $\mathrm{z}$ untuk data kategori ordinal dan t-test untuk perbedaan kelompok eksperimen dan kontrol. Hasil penelitian menunjukkan sebagian besar karakteristik umur $>40$ tahun dan jenis kelamin perempuan dengan jenis kanker payudara. Kesimpulan diperoleh, pelatihan mindfulness dapat memberikan manfaat bagi pasien kanker dalam mencapai relaksasi guna menurunkan kecemasan pada saat menghadapi pengobatan dengan tindakan kemoterapi, sehingga dengan demikian dapat meningkatkan kesadaran untuk lebih menerima situasi kondisi yang sedang terjadi. Saran agar petugas kesehatan baik perawat maupun dokter dapat melatih pasien yang mengalami kecemasan dalam menghadapi kemoterapi atau tindakan invasif lainnya.
\end{abstract}

Kata Kunci: Minfulness, kecemasan, pasien kanker

\section{Latar Belakang}

Kanker termasuk salah satu penyakit tidak menular yang menjadi penyebab kematian terbesar di seluruh dunia. Kanker dikenal merupakan 
sekelompok penyakit yang ditandai dengan pertumbuhan tidak terkendali sel-sel tubuh tertentu yang berakibat merusak sel dan jaringan tubuh lain, bahkan sering berakhir kematian. Karena sifatnya demikian ganas tumbuh tak terkendali dan menyebabkan kematian, maka kanker juga disebut sebagai penyakit keganasan dan sel kanker juga disebut sel ganas. Semua sel tubuh dapat terkena kanker kecuali rambut, gigi, dan kuku (Güneş, Z and Çalışır, H. 2016; Samantha, W. 2015).

Menurut data Departemen Kesehatan, kanker merupakan penyebab kematian nomor 7 di Indonesia. kanker payudara menduduki peringkat kedua yang dialami wanita setelah kanker leher rahim, dan merupakan penyebab utama kematian pada wanita. Daerah dengan penderita kanker terbanyak di Indonesia adalah Yogyakarta. Di daerah tersebut, tingkat prevalensi tumor mencapai 9,6 per 1000 orang. Di Indonesia, prevalensi kanker pada semua jenis usia adalah sebesar 0,14\%. Jenis kanker yang kerap kali menyerang adalah kanker paru, kanker payudara, kanker hati, dan kanker serviks. Di provinsi DIY prevalensi tertinggi adalah $0,41 \%$. Dari sekian banyak jenis kanker, kanker serviks dan payudara menempati urutan tertinggi di Indonesia. Kanker payudara paling luas penyebarannya di propinsi kepulauan Riau dan Maluku Utara. Daerah Istimewa Yogyakarta memiliki jumlah tertinggi dari penderita kanker serviks di seluruh Indonesia (Depkes, 2010).

Penyakit kanker serviks dan payudara merupakan penyakit kanker dengan prevalensi tertinggi di Indonesia pada tahun 2013, yaitu kanker serviks sebesar 0,8\% dan kanker payudara sebesar 0,5\%. Provinsi Kepulauan Riau, Provinsi Maluku Utara, dan Provinsi D.I. Yogyakarta memiliki prevalensi kanker serviks tertinggi yaitu sebesar 1,5\%o, sedangkan prevalensi kanker payudara tertinggi terdapat pada Provinsi D.I. Yogyakarta, yaitu sebesar 2,4\%o. Berdasarkan estimasi jumlah penderita kanker serviks dan kanker payudara terbanyak terdapat pada Provinsi Jawa Timur dan Provinsi Jawa Tengah. Prevalensi kanker prostat di Indonesia tahun 2013 adalah sebesar 0,2\%o atau diperkirakan sebanyak 25.012 penderita. Provinsi yang memiliki prevalensi kanker prostat tertinggi adalah D.I. Yogyakarta, Bali, Sulawesi Utara, dan Sulawesi Selatan yaitu sebesar 0,5\%o, 
sedangkan berdasarkan estimasi jumlah penderita penyakit kanker prostat terbanyak berada pada Provinsi Jawa Timur dan Provinsi Jawa Tengah (Pamungkas, 2011).

Misalnya, penanganan kanker payudara selain program SADARI dibutuhkan juga kepatuhan pasien kanker dalam melakukan kemoterapi, karena kedua hal ini secara jangka panjang mampu menurunkan morbiditas dan mortalitas penderitanya. Patuh melanjutkan program kemoterapi maka dapat menghambat dan membunuh sel kanker dan menurunkan resiko terjadinya kematian (Aruan, KP. \& Isfandiari, MA. 2016; Nikbakhsh, N., et al. 2014). Kemoterapi digunakan pada tahap awal untuk mengendalikan sel-sel kanker yang mungkin masih tertinggal setelah dilakukan pembedahan, serta untuk mengurangi resiko kanker datang kembali, pada beberapa kasus kemoterapi diberikan setelah pembedahan ini disebut kemoterapi (adjuvean), ada juga yang diberikan sebelum dilakukan pembedahan bertujuan untuk menyusutkan kanker dan ini biasa disebut (non-adjuvean) (Narod, et al., 2013; Pamungkas, 2011).

Kecemasan merupakan salah satu keadaan psikologis yang biasa terjadi karena pengalaman yang tidak menyenangkan yang dialami oleh setiap manusia, maka tidak mengherankan jika kecemasan terjadi pada manusia yang mengalami gangguan fisik, hingga $50 \%$ pasien medis melaporkan secara klinis mengalami kecemasan. Kecemasan juga merupakan suatu keadaan khawatir, gugup atau takut ketika berhadapan dengan pengalaman yang sulit dalam kehidupan seseorang dan menganggap bahwa sesuatu yang buruk akan terjadi. Simptom kecemasan sangat berbeda dan bervariasi untuk setiap individu. Simptom kecemasan dapat mengganggu kualitas hidup seseorang karena dapat mempengaruhi kemampuan seseorang untuk menjalankan berbagai aktifitas (Khalil.,et al, 2014).

Salah satu pendekatan terapi yang dapat menangani kecemasan adalah terapi kognitif-behavioral dengan mengembangkan cara berfikir yang lebih adaptif yaitu mindfuness. Mindfuness memiliki kesamaan dengan pendekataan kognisi dan perilaku dalam beberapa hal, antara lain perubahan kognisi sebagai hasil dari mengobservasi pikiran sebagai fenomena yang sesaat tanpa arti, bukan 
sebagai refleksi yang akurat dari kenyataan. Mindfulness merupakan suatu bentuk meditasi pikiran yang melibatkan pemusatan perhatian pada setiap peristiwa dari seluruh pengalaman hidup tanpa memperdulikan apakah pengalaman tersebut hebat atau hanya biasa-biasa saja. Pelatihan mindfulness merupakan suatu metode meditasi yang dapat meningkatkan empati dan terdiri dari kombinasi dimensi afektif, kognitif, moral, intrapersonal dan interpersonal (Simkin, \& Black, 2014).

Nikbakhsh, et al., (2014) menjelaskan pelatihan mindfulness akan menyebabkan individu belajar menyadari pengalaman saat ini dengan keterbukaan dan rasa ingin tahu, menerima pengalaman hidup apa adanya tanpa keinginan untuk menghakimi atau mengubahnya. Pelatihan mindfulness mengajarkan individu untuk mengembangkan kemampuan dalam mengatur pengalihan pusat kesadaran/perhatian dari satu target ke target yang lain serta mengobservasi keadaan mentalnya. Pandangan utama metode mindfulness adalah pikiran kita sendiri yang membentuk dunia, dan hal ini memiliki kesamaan dengan pandangan teori kognitif behavioral. Pada penelitian tersebut Rosenzweig juga berhasil membuktikan bahwa metode mindfulness dapat menurunkan depresi, kecemasan dan stres psikologis pada penderita diabetes tipe-2. Pendekatan mindfulness juga didasarkan pada aspek kognisi dan perilaku namun dengan pengembangan yang berbeda. Pelatihan program mindfulness yang digunakan dalam penelitian tersebut diadaptasi dari program mindfulness yang didesain oleh Jon Kabat-Zinn. Penelitian ini dilakukan di Yayasan Kanker Indonesia Yogyakarta.

Adapun tujuan penelitian adalah untuk mengetahui manfaat pelatihan mindfulness dalam menurunkan kecemasan pasa pasien kanker dengan kemoterapi. Sedangkan tujuan khusus adalah untuk mengetahui karakteristik pasien kanker yang melakukan kemoterapi, mengetahui perbedaan kecemasan pasien kanker yang menjalani kemoterapi, dan mengetahui perbedaan rerata kecemasan sebagai efek pemberian pelatihan mindfulness

\section{Metodologi}


Jenis penelitian ini adalah Quasi eksperiment dengan menggunakan rancangan pretest and posttest control group design. Untuk mengetahui perbedaan kecemasan yang terjadi karena pengaruh dari perlakuan maka rancangan ini dibuat dua kelompok yaitu kelompok eksperimen dan kontrol diseleksi serupa dikutip dalam Shadish, Cook, \& Campbell, (2002). Populasi adalah semua pasien kanker yang akan menjalani kemoterapi pada Yayasan Kanker Indonesia di Yogyakarta selama 2 bulan berturut-turut. Pasien yang menjalani tindakan prosedur kemoterapi pada tahun 2016 berjumlah 608 pasien dengan rata-rata perbulan 50 pasien. Berdasarkan populasi yang ada ditentukan subyek penelitian yang terdiri dari kasus dan kontrol dengan kriteria tertentu yang ditetapkan berdasarkan tujuan penelitian.

Secara keseluruhan jumlah sampel penelitian ini sebesar 60 orang meliputi 30 orang kelompok perlakuan dan 30 orang kelompok kontrol. Pemilihan sampel dengan tehnik probability sampling yaitu simple random sampling melalui cara undian. Tehniknya adalah sebagai berikut: setelah penetapan jumlah sampel, peneliti bersama enumerator melakukan pengundian untuk memilih responden pada setiap pasien kanker yang akan melakukan kemoterapi. Pasien yang terpilih dan bersedia harus menandatangani informed consent. Penentuan kelompok experiment dan kontrol dilakukan pada waktu dan tempat yang berbeda.

Analisis data yang dilakukan adalah uji Mann Whitney karena menguji kelompok eksperimen dan kontrol. Pada data kategorik dilakukan uji Mann Whitney, sedangkan data numerik dilakukan uji t.

\section{Hasil Penelitian}

Penelitian ini dilakukan pada Rumah Singgah Yayasan Kanker Indonesia di Yogyakarta. Subyek yang memenuhi syarat berdasarkan kriteria inklusi berjumlah 60 responden, selanjutnya dibagi menjadi yaitu 30 responden kelompok eksperimen dan 30 responden kelompok kontrol yang ikut berpartisipasi dalam penelitian tersebut. Kelompok eksperimen diberikan pelatihan mindfulness dan kontrol diberikan penyuluhan. Pengambilan data dilakukan dua kali yaitu pre dan post setelah diberikan pelatihan mindfulness 
sebanyak dua sesi baik pada kelompok eksperimen dan satu sesi penyuluhan pada kelompok kontrol.

Karakteristik responden yang berpartisipasi pada penelitian ini dapat dilihat pada tabel berikut:

Tabel 1. Distribusi Responden Berdasarkan Umur dan Jenis Kelamin

\begin{tabular}{llccccc}
\hline \multirow{2}{*}{ No } & Variabel & Kategori & \multicolumn{2}{c}{ Eksperimen $(\mathrm{n}=30$} & \multicolumn{2}{c}{ Kontrol $(\mathrm{n}=30$} \\
& & & $\mathrm{f}$ & $\%$ & $\mathrm{f}$ & $\%$ \\
\hline 1 & \multirow{2}{*}{ Umur } & $<40$ & 9 & 30 & 7 & 23,3 \\
& & $>40$ & 21 & 70 & 23 & 76,7 \\
2 & \multirow{2}{*}{ Jenis Kelamin } & Laki-laki & 4 & 13,3 & 6 & 20 \\
& & Perempuan & 26 & 86,7 & 24 & 80 \\
\hline
\end{tabular}

Tabel 1 menyatakan umur responden $>40$ tahun terbanyak dengan jumlah 21 resopnden $(70 \%)$ pada kelompok eksperimen, demikian juga dengan kelompok kontrol $>40$ tahun 23 responden $(76,7 \%)$. Jenis kelamin terbanyak pada kelompok eksperimen adalah perempuan yaitu 26 responden $(86,7 \%)$, juga pada kelompok kontrol 24 responden (80\%).

Tabel 2. Distribusi Frekuensi Pelatihan Mindfulness dan Jenis Kanker

\begin{tabular}{|c|c|c|c|c|c|c|}
\hline \multirow[t]{2}{*}{ No } & \multirow[t]{2}{*}{ Variabel } & \multirow[t]{2}{*}{ Kategori } & \multicolumn{2}{|c|}{ Eksperimen $(n=30$} & \multicolumn{2}{|c|}{ Kontrol $(n=30$} \\
\hline & & & $\mathrm{f}$ & $\%$ & $\mathrm{f}$ & $\%$ \\
\hline \multirow[t]{2}{*}{1} & Ikut serta pelatihan & Pernah & 3 & 10 & 4 & 13,3 \\
\hline & & Tidak pernah & 27 & 90 & 26 & 86,7 \\
\hline \multirow[t]{4}{*}{2} & Jenis Kanker & Payudara & 24 & 80,2 & 24 & 80,2 \\
\hline & & Darah & 3 & 10 & 2 & 6,6 \\
\hline & & Prostat & 2 & 6,6 & 2 & 6,6 \\
\hline & & Kulit & 1 & 3,2 & 2 & 6,6 \\
\hline
\end{tabular}

Tabel 2 menggambarkan tentang keikutsertaan pelatihan mindfulness terbanyak pada kategori tidak pernah yaitu 27 responden (90\%) pada kelompok eksperimen, demikian juga dengan kelompok kontrol 26 responden (86,7\%). Jenis kanker terbanyak pada kelompok eksperimen adalah kanker payudara yaitu 24 responden $(80,2 \%)$, juga pada kelompok kontrol 24 responden $(80,2 \%)$.

Data tersebut di analisis dengan chi-square test untuk mengetahui hubungan atau perbedaan antara kelompok eksperimen dan kontrol berdasarkan variabel umur, jenis kelamin, keikutsertaan pelatihan mindfulness, dan jenis kanker. 
Tabel 3. Distribusi Umur, Jenis Kelamin, Keikutsertaan Pelatihan, dan Jenis Kanker

\begin{tabular}{llcc}
\hline Variabel & \multicolumn{1}{c}{ Kelompok } & $\mathrm{p}$ & $\alpha$ \\
\hline Umur & Eksperimen & 0,770 & $>0,05$ \\
Kenis Kelamin & $\begin{array}{l}\text { Kontrol } \\
\text { Eksperimen } \\
\text { Kontrol }\end{array}$ & 0,729 & $>0,05$ \\
Keikutsertaan Pelatihan & $\begin{array}{l}\text { Eksperimen } \\
\text { Kontrol } \\
\text { Jenis Kanker }\end{array}$ & 1,000 & $>0,05$ \\
& $\begin{array}{l}\text { Eksperimen } \\
\text { Kontrol }\end{array}$ & 0,912 & $>0,05$ \\
\hline \multicolumn{1}{c}{ Tabel 3 menunjukan nilai } & p pada variabel umur, jenis kelamin
\end{tabular}

keikutsertaan pelatihan dan jenis kanker adalah lebih besar 0,05 artinya tidak terdapat perbedaan antara kelompok eksperimen dan kontrol pada data tersebut.

Uji statistik yang paling tepat pada data tersebut adalah Mann Whitney, karena data kecemasan termasuk jenis data kategorik ordinal. Oleh karena itu, data ini dianalisis dengan Mann Whitney. Akan tetapi, sebagai perbandingan hasil, akan dilakukan uji t antar kelompok eksperimen dengan kontrol, yang dapat dilihat sebagai berikut:

Tabel 4. Distribusi Kelompok Berdasarkan Kecemasan (Whitney Test)

\begin{tabular}{llccc}
\hline Kecemasan & Kelompok & $\mathrm{z}$ & Delta & $\mathrm{p}$ \\
\hline Pre-test & $\begin{array}{l}\text { Eksperimen } \\
\text { Kontrol }\end{array}$ & 0,000 & 0,000 & 1,000 \\
Eksperimen & & & 0,000 \\
\hline Post-test & Kontrol & & & \\
\hline
\end{tabular}

Tabel 4 menggambarkan pada pre-test bahwa nilai p uji Mann Whitney sebesar 1,000 sehingga $>\alpha(0,05)$. Artinya tidak terdapat perbedaan pretest kecemasan antara kelompok eksperimen dan kontrol. Sedangkan post-test nilai $\mathrm{p}$ uji Mann Whitney sebesar 0,000 sehingga $<\alpha(0,05)$. Artinya terdapat perbedaan post-test kecemasan antara kelompok eksperimen dan kontrol.

Tabel 5. Distribusi Kelompok Berdasarkan Data Kecemasan (t-test)

\begin{tabular}{lllcc}
\hline Kecemasan & Kelompok & Mean & Delta & $\mathrm{p}$ \\
\hline Pre-test & Eksperimen & 38,43 & & 0,896 \\
\multirow{2}{*}{ Post-test } & Kontrol & 38,36 & 13,766 & \\
& Eksperimen & 52,20 & & 0,000 \\
\hline
\end{tabular}

Berdassarkan tabel di atas, terdapat rerata/mean kelompok eksperimen 52,2 sedangkan kelompok kontrol 38,2. Artinya, kelompok kontrol memiliki kecemasan lebih tinggi dibandingkan kelompok eksperimen. 
Nilai $\mathrm{p}$ uji $\mathrm{t}$ sebesar 0,896 sehingga $>\alpha(0,05)$. Artinya tidak terdapat perbedaan pre-test kecemasan antara kelompok eksperimen dan kontrol. Sedangkan nilai $\mathrm{p}$ uji $\mathrm{t}$ sebesar 0,000 sehingga $<\alpha(0,05)$. Artinya, terdapat perbedaan post-test kecemasan antara kelompok eksperimen dan kontrol.

Nilai delta dicari dengan mengurangkan nilai post dan pre. Skor post test kelompok eksperimen lebih besar dibandingkan kelompok kontrol $(52,20>38,43)$. Skor yang lebih besar menunjukkan kecemasan yang semakin rendah, karena skoring jawaban responden $1=$ cemas dan $2=$ tidak cemas.

Data Pre-test dan post-test pada kelompok eksperimen dan kontrol dapat dilihat pada grafik berrikut:

Grafik 1. Distribusi Responden Pre-test Kelompok Eksperimen dan Kontrol

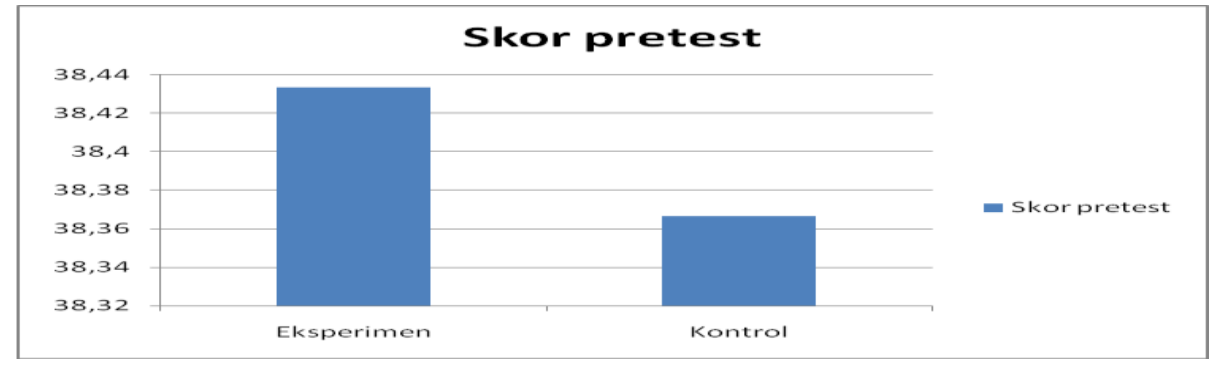

Grafik 2. Distribusi Responden Post-test Klompok Eksperimen dan Kontrol

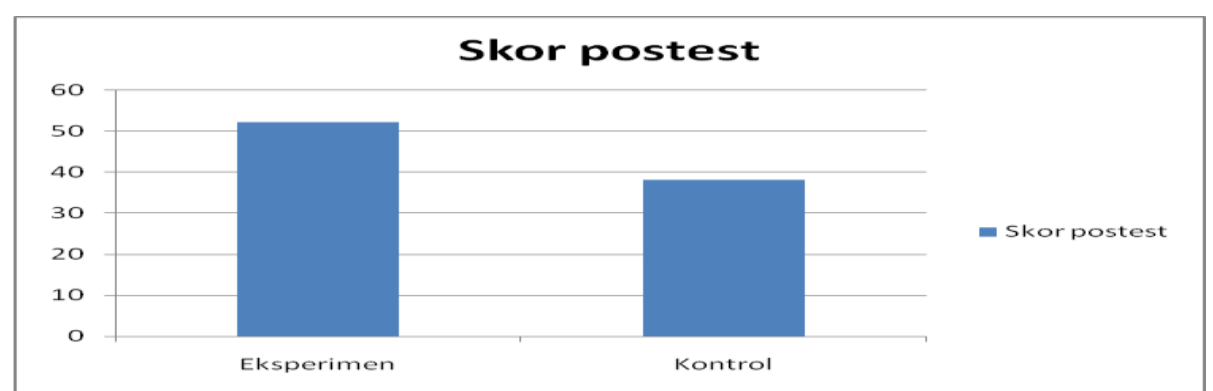

\section{Diskusi}

Umur responden $>40$ tahun adalah golongan umur terbanyak $(70-76,7 \%)$ pada kedua kelompok penelitian tersebut. Demikian juga dengan jenis kelamin terbanyak pada kelompok eksperimen adalah perempuan yaitu 26 responden 
(86,7\%), juga pada kelompok kontrol 24 responden (80\%). Studi epidemiologi sebelumnya menunjukkan bahwa usia pasien kanker di Indonesia lebih muda daripada di negara maju. Lebih dari 30\% kasus didapat pada pasien berumur 40 tahun atau lebih muda, sedangkan di negara maju, pasien yang umurnya kurang dari 50 tahun hanya 2-8 \% saja (Nurcahyo, 2010). Demikian juga dengan jenis kelamin, Jakarta Cancer Registry, bahwa kanker kolorektal menempati urutan keempat untuk kanker yang menyerang wanita (3.15 per 100.000) dan menempati urutan kedua (4.13 per 100.000) untuk kanker yang menyerang laki-laki.

Umur dan jenis kelamin responden pada penelitian ini adalah terbanyak pada usia di atas 40 tahun dan terjadi pada wanita. Data membuktikan bahwa di Indonesia khususnya Yogyakarta kanker payudara dan kanker serviks menempati urutan tertinggi dan berdasarkan umur terjadi pada usia di atas 50 tahun. Rumah singgah Yayasan Kanker Indonesia di Yogyakarta memberikan fasilitas kepada pasien kanker untuk dapat tinggal di rumah singgah tersebut dengan biaya yang relatif sangat murah dan pada umumnya pasien kanker yang memanfaatkan rumah singgah tersebut adalah wanita berusia lanjut karena merasa lebih dekat dengan sumber pelayanan kesehatan yaitu Rumah Sakit Sarjito ketika harus melakukan kemoterapi.

Pelatihan mindfulness sangat jarang dilakukan pada Yayasan Kanker Indonesia di Yogyakarta terutama di rumah singgah, sehingga merupakan salah satu alasan melakukan pelatihan mindfulness dalam mengurangi kecemasan pasien kanker yang sedang menjalani kemoterapi, sehingga data pre-test diperoleh $90 \%$ responden belum pernah mengikuti pelatihan tersebut. Berdasarkan jumlah di atas jenis kanker payudara 24 responden $(80,2 \%)$ pada kelompok eksperimen dan 24 responden $(80,2 \%)$ pada kelompok kontrol, menempati urutan tertinggi dibandingkan jenis kanker yang lain.

Untuk mengetahui hubungan atau perbedaan antara kelompok eksperimen dan kontrol berdasarkan variabel umur, jenis kelamin, keikutsertaan pelatihan mindfulness, dan jenis kanker, maka dilakukan analisis dengan chi-square test. Hasil uji diperoleh nilai $\mathrm{p}$ pada variabel umur, jenis kelamin, keikutsertaan 
pelatihan dan jenis kanker adalah lebih besar $(>0,05)$ artinya tidak terdapat perbedaan antara kelompok eksperimen dan kontrol pada data tersebut.

Pada perbedaan kecemasan sebagai efek pemberian pelatihan mindfulness, uji statistik yang paling tepat pada data tersebut adalah Mann Whitney, karena data kecemasan termasuk jenis data kategorik ordinal. Oleh karena itu, data tersebut dianalisis dengan Mann Whitney. Akan tetapi, sebagai perbandingan hasil, maka dilakukan uji t antar kelompok eksperimen dengan kontrol.

Hasil pre-test bahwa nilai p uji Mann Whitney sebesar 1,000 sehingga $>\alpha$ $(0,05)$. Artinya, tidak terdapat perbedaan pretest kecemasan antara kelompok eksperimen dan kontrol. Sedangkan post-test nilai p uji Mann Whitney sebesar 0,000 sehingga $<\alpha(0,05)$. Artinya terdapat perbedaan post-test kecemasan antara kelompok eksperimen dan kontrol. Menurut Khalil, A., et al. (2016), bahwa kecemasan akan semakin bertambah pada orang yang mengalami penyakit kanker karena proses pengobatannya panajang dan mahal, sehingga membutuhkan kesabaran dan kesadaran pasien untuk tetap berada pada pengobatan jalur medis.

Mendukung hasil penelitian Shader, R.I. \& Taylor, S. (2017), bahwa individu yang mengalami gangguan kesehatan adalah rentan mengalami masalah psikologis, diantaranya kecemasan. Kecemasan yang tinggi dan berkepanjangan dapat memperparah penyakit yang diderita. Demikian juga Simkin, D.R \& Black, N.B. (2014), menjelaskan bahwa pelatihan mindfulness dapat mengurangi kecemasan karena memberikan relaksasi pagi orang yang mengalami gangguan kesehatan.

Manfaat pelatihan mindfulness diantaranya adalah dapat mengurangi perasaan menderita serta mencapai perasaan nyaman dan sejahtera pada setiap situasi dan kondisi. Demikian juga mindfulness dapat menumbuhkan sikap menghargai terhadap diri sendiri dan orang lain, sehingga dengan demikian setiap orang tidak menyalahkan diri sendiri dan mengurangi perasaan bersalah.

Pada perbedaan rerata kecemasan pada kelompok eksperimen dan control. Hasil uji perbedaan rerata kecemasan pada kelompok eksperimen 52,2 sedangkan kelompok kontrol 38,2. Artinya, kelompok kontrol memiliki kecemasan lebih tinggi dibandingkan kelompok eksperimen. Data tersebut memberikan gambaran bahwa 
kelompok eksperimen yang diintervensi dengan pelatihan mindfulness lebih rendah kecemasannya dibandingkan dengan kelompok kontrol. Seperti hasil penelitian Maráz, et al. (2014), bahwa pasien yang mengalami kanker dan sedang menjalani kemoterapi sangat membutuhkan ketenangan jiwa dan kesadaan untuk dapat menerima secara sadar bahwa kemoterapi adalah bagian dari penyembuhan yang diharapkan. Demikian pula kecemasan yang dialami penderita kanker darah atau leukemia anak adalah kecemasan parah, sedang dan ringan. Efek latihan kewaspadaan terhadap pengurangan kecemasan pada pasien kanker atau leukemia menjadi tingkat kecemasan sedang dan parah menjadi lebih ringan.

Pada nilai $\mathrm{p}$ uji t sebesar 0,896 sehingga $>\alpha(0,05)$. Artinya tidak terdapat perbedaan pre-test kecemasan antara kelompok eksperimen dan kontrol. Sedangkan nilai $\mathrm{p}$ uji t sebesar 0,000 sehingga $<\alpha(0,05)$. Artinya, terdapat perbedaan post-test kecemasan antara kelompok eksperimen dan kontrol. Perbedaan yang dialami kelompok eksperimen merupakan manfaat atau efek dari pemberian mindfulness. Dengan demikian dapat disimpulkan berdasarkan hasil rerata tersebut bahwa pelatihan mindfulness dapat memberikan manfaat bagi pasien kanker dalam mengurangi kecemasan pada saat menghadapi pengobatan dengan tindakan kemoterapi.

\section{Kesimpulan \& Saran}

Tindakan kemoterapi pada pasien kanker belum sepenuhnya dapat diterima oleh pasien kanker, sehingga tindakan tersebut menjadi stressor tersendiri bagi yang bersangkutan. Pada umumnya pasien yang harus menjalani kemoterapi, mengalami kecemasan yang dapat mengganggu prosedur pengobatan, sehingga hal ini harus diantisipasi.

Pelatihan mindfulness sangat jarang dilakukan pada Yayasan Kanker Indonesia di Yogyakarta terutama di rumah singgah, sehingga merupakan salah satu alasan melakukan pelatihan mindfulness dalam mengurangi kecemasan pasien kanker yang sedang menjalani kemoterapi. 
Pelatihan mindfulness dapat memberikan manfaat bagi pasien kanker dalam mencapai relaksasi pada saat menghadapi pengobatan dengan tindakan kemoterapi, sehingga dengan demikian dapat meningkatkan kesadaran untuk lebih menerima situasi kondisi yang sedang terjadi.

Guna meningkatkan kesadaran terhadap tindakan kemoterapi pada pasien kanker, maka sebelum menjalani kemoterapi, pasien dapat melakukan mindfulness untuk dirinya sendiri.

Pelatihan mindfulness sangat sederhana namun besar manfaatnya, sehingga diharapkan dapat dikuasai oleh setiap petugas kesehatan terutama dokter dan perawat agar dapat melatih pasien sesuai kebutuhannya.

\section{DAFTAR PUSTAKA}

Altundag, K. (2017). Comment on "Chemotherapy-Induced left ventricular dysfunction in patients with breast cancer". International Journal Breast Cancer, 20(1); 112-113

Aruan, KP. \& Isfandiari, MA. (2016). Hubungan dukungan sosial terhadap pengobatan kanker payudara di Yayasan kanker Wisnuwardhana. Jurnal Promkes, 3(2); 218-228.

Depkes. (2010). Kanker Payudara (online). Diakses pasa tanggal 10 Oktober 2016.

Güneş, Z and Çalışır, H. (2016). Quality of Life and Social Support in Cancer Patients Undergoing Outpatient Chemotherapy in Turkey. Annals of Nursing and Practice, 3(7): 1070-1077.

Khalil, A., Faheem, M., Fahim, A., Innocent, H., Mansoor., Rizvi, S., and Farrukh, H. (2016). Prevalence of Depression and Anxiety amongst Cancer Patients in a Hospital Setting: A Cross-Sectional Study, Psychiatry Journal, 6, 7177

Maráz, R., Boross, G., Pap-Szekeres, J., Rajtár, M., Ambrózay, E., Cserni, G. (2014). Internal Mammary Sentinel Node Biopsy in Breast Cancer. Is it Indicated?, Journal Pathology Oncology Res., 20:169-177.

Narod, S.A., Metcalfe, K., Lynch, H.T. Ghadirian, P., Robidoux, A. (2013). Should all BRCA1 mutation carriers with stage I breast cancer receive 
chemotherapy? Journal of Breast Cancer Research and Treatment, 138.1 273-9.

Nikbakhsh, N., Moudi, S., Abbasian, S., Khafri, S. (2014). Prevalence of depression and anxiety among cancer patients, Caspian Journal Intern Med. 5, 3, 167170 .

Nurcahyo. (2010). Awas!!! Bahaya Kanker Rahim dan Kanker Payudara. Yogyakarta: wahana totalita publisher.

Pamungkas. (2011). Deteksi Dini Kanker Payudara. Yogyakarta: Buku Biru.

Shader, R.I. \& Taylor, S. (2017). Some Reflections on Meditation and Mindfulness, Journal of Clinical Psychopharmacology, 27, 1, 2-5.

Samantha, W. (2015). Defining cancer survivor and cancer survivorship: the who, what, and when, Phsycooncología,12, 1, 7-18

Simkin, D.R \& Black, N.B. (2014). Meditation and Mindfulness in Clinical Practice. Child Adolesc Psychiatr Clin N Am. 23, 3, 487-534.

Shadish, W.R., Cook, Th.D., \& Campbell, D.T (2012). Experimental and QuasiExperimental design for generalized Causal Inference. New York Houghton Mifflin Company

Wheeler, S.B., Carpenter, W.R., Peppercorn, J., Schenck, A., Weinberger, M. (2012). Predictors of timing of adjuvant chemotherapy in older women with hormone receptor-negative, stages II-III breast cance. Breast Cancer Research and Treatment, 131.1, 207-216. 